\title{
Micromonospora lupini sp. nov. and Micromonospora saelicesensis sp. nov., isolated from root nodules of Lupinus angustifolius
}

Correspondence Martha E. Trujillo mett@usal.es

\author{
Martha E. Trujillo, ${ }^{1}$ Reiner M. Kroppenstedt, ${ }^{2}$ Carmen Fernández- \\ Molinero, ${ }^{1}$ Peter Schumann ${ }^{2}$ and Eustoquio Martínez-Molina ${ }^{1}$
}

\footnotetext{
${ }^{1}$ Departamento de Microbiología y Genética, Edificio Departamental, Lab. 209, Campus Miguel de Unamuno, Universidad de Salamanca, Salamanca, Spain

${ }^{2}$ DSMZ - Deutsche Sammlung von Mikroorganismen und Zellkulturen GmbH, Mascheroder Weg 1b, 38124 Braunschweig, Germany
}

\begin{abstract}
A study was conducted to determine the taxonomic status of six actinomycete strains isolated from root nodules of Lupinus angustifolius. The strains were filamentous, Gram-positive and produced single spores at the tip of the hyphae. Phylogenetic, chemotaxonomic and morphological analyses demonstrated that all six strains belonged to the genus Micromonospora. According to the 16S rRNA gene sequence data, the strains were divided into two clusters that are moderately related to Micromonospora mirobrigensis, Micromonospora matsumotoense and Micromonospora purpureochromogenes. Fatty acid patterns also supported the division of the strains, and significant differences between the two groups were found in the amounts of iso- $15: 0$, iso-16:0, iso-16:1 and iso-17:0. Furthermore, the two groups showed physiological differences which included utilization of arabinose, trehalose, alanine and sucrose and xylan hydrolysis. Finally, DNA-DNA hybridization and ribotyping studies confirmed that each group represents a novel species. Based on the genotypic and phenotypic data, the novel species Micromonospora lupini sp. nov. (type strain Lupac $14 \mathrm{~N}^{\top}=\mathrm{DSM} 44874^{\top}=\mathrm{LMG} 24055^{\top}$ ) and

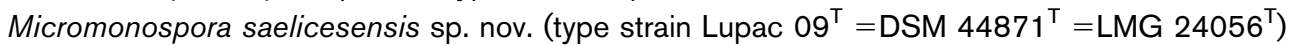
are proposed.
\end{abstract}

The genus Micromonospora Ørskov 1923, a member of the family Micromonosporaceae (Stackebrandt et al., 1997), forms a stable group based on phylogenetic, chemotaxonomic and morphological data (Lechevalier \& Lechevalier, 1970; Kroppenstedt, 1985; Lechevalier et al., 1977; Stackebrandt et al., 1997). Members of Micromonospora are widely distributed in aquatic, marine and terrestrial environments (Kawamoto, 1989; Zhao et al., 2004; Maldonado et al., 2005) but, recently, members of this genus have also been recovered from diverse plant tissues, especially nitrogen-fixing root nodules (Valdés et al., 2005; Trujillo et al., 2006b; M. E. Trujillo, unpublished observations). During an ecological study of nitrogen-fixing

\footnotetext{
Abbreviation: DAP, diaminopimelic acid.

The GenBank/EMBL/DDBJ accession numbers for the 16S rRNA sequences of isolates Lupac 06, Lupac 07, Lupac 08, Lupac 09 ${ }^{\top}$, Lupac 13 and Lupac $14 \mathrm{~N}^{\top}$ are respectively AJ783990-AJ783993, AJ783995 and AJ783996.

Scanning electron micrographs of spores of strains Lupac $09^{\top}$ and Lupac $14 \mathrm{~N}^{\top}$, an extended phylogenetic tree, cultural characteristics of the novel strains and detailed fatty acid profiles are available as supplementary material with the online version of this paper.
}

bacterial communities from Lupinus angustifolius collected in Spain, different orange-pigmented actinomycete colonies were isolated from surface-sterilized nodules on yeast extract-mannitol agar (YMA) (Vincent, 1970). The results of a detailed taxonomic study of six isolates indicate that these strains represent two novel species.

Strains Lupac 06, Lupac 07, Lupac 08, Lupac 09 ${ }^{\mathrm{T}}$, Lupac 13 and Lupac $14 \mathrm{~N}^{\mathrm{T}}$ were isolated from surface-sterilized nitrogen-fixing nodules of Lupinus angustifolius collected in Saelices el Chico (Salamanca, Spain) following the procedure described previously (Trujillo et al., 2006a). Isolation plates were incubated for 2 weeks at $28{ }^{\circ} \mathrm{C}$, after which colonies were picked under a stereoscopic microscope. All strains were Gram-stained using the procedure described by Doetsch (1981). Morphological and cultural characteristics of the strains were determined using various agar media: ISP 2 and ISP 3 (Shirling \& Gottlieb, 1966), SA1 (Trujillo et al., 2005), Bennett's (Jones, 1949) and N-Z amine, which contained $\left(1^{-1}\right) 10.0 \mathrm{~g}$ glucose, $20.0 \mathrm{~g}$ soluble starch, 5.0 g yeast extract, $5.0 \mathrm{~g} \mathrm{~N}-\mathrm{Z}$ amine, $1.0 \mathrm{~g} \mathrm{CaCO}_{3}$, and $15.0 \mathrm{~g}$ agar. (DSM medium 554; DSMZ catalogue). Cell morphology and motility were observed by phasecontrast microscopy using 5-day-old cultures on SA1 agar 
(Leica; CTR MIC). Isolates Lupac $09^{\mathrm{T}}$ and Lupac $14 \mathrm{~N}^{\mathrm{T}}$ were fixed, dehydrated, critical-point-dried and coated with gold before examination by scanning electron microscopy (Zeiss; DSM 940).

All strains grew well on all media tested, except that isolates Lupac 13 and Lupac $14 \mathrm{~N}^{\mathrm{T}}$ grew poorly or did not grow, respectively, on Bennett's agar. Colonies of all strains ranged from light orange to brown on the different media and were folded and raised, and some of them turned dark brown to black after spore production. Orange-brown and brown diffusible pigments were produced by strains Lupac $09^{\mathrm{T}}$, Lupac 06 and Lupac 07 on ISP 3 agar. All strains were Gram-positive, produced branched hyphae $(0.3-0.6 \mu \mathrm{m}$ diameter) with terminal spores and lacked aerial mycelium. Strains Lupac $09^{\mathrm{T}}$ and Lupac $14 \mathrm{~N}^{\mathrm{T}}$ formed single spores (0.6-0.8 $\mu \mathrm{m}$ diameter), mainly on long hyphae. The spores had a 'lemon-shaped' form and presented a smooth surface (Supplementary Fig. S1, available in IJSEM Online). Cultural characteristics of the six strains in all tested media are presented in Supplementary Table S1.

DNA extraction and PCR amplification of the 16S rRNA gene were performed using the REDExtract-N-Amp Plant PCR kit (Sigma) following the manufacturer's instructions but with an additional purification step using phenol/ chloroform. Amplification and sequencing conditions followed methods described by Rivas et al. (2003).

The six sequences obtained were aligned manually and compared with corresponding sequences of all species of the genus Micromonospora with validly published names downloaded from GenBank/EMBL. Phylogenetic distances were calculated with Kimura's two-parameter model (Kimura, 1980) and tree topologies were inferred using the maximum-parsimony (Fitch, 1971) and neighbourjoining (Saitou \& Nei, 1987) methods. Branch support based on 1000 replications was calculated with the bootstrap test. All analyses were carried out using the MEGA3 program (Kumar et al., 2004).

Nearly complete $16 \mathrm{~S}$ rRNA gene sequences (1460 nt) were obtained for the six isolates and confirmed their phylogenetic affiliation to the genus Micromonospora. Identification of the closest phylogenetic neighbours and calculation of pairwise 16S rRNA gene sequence similarities were achieved using the EzTaxon server (http://www.eztaxon.org/; Chun et al., 2007). Sequence similarities between the new isolates and currently described Micromonospora species ranged from 96.7 to $99.0 \%$. Lupac $14 \mathrm{~N}^{\mathrm{T}}$ showed $98.5 \%$ sequence similarity to Micromonospora mirobrigensis DSM $44830^{\mathrm{T}}$, while Lupac $09^{\mathrm{T}}$ shared $98.7 \%$ sequence similarity with Micromonospora purpureochromogenes DSM $43821^{\mathrm{T}}$ and Micromonospora matsumotoense DSM $44110^{\mathrm{T}}$. Two different lineages were revealed by the phylogenetic analysis: isolates Lupac 06, Lupac 07 and Lupac $09^{\mathrm{T}}$ (group A), sharing sequence similarity of $99.6-99.7 \%$, formed a compact cluster, while strains Lupac 08, Lupac 13 and Lupac $14 \mathrm{~N}^{\mathrm{T}}$ (group B) formed an independent branch and shared sequence similarity of $99.6-100 \%$. Members of the two clusters showed sequence similarity between 98.8 and $99.1 \%$ and the clusters were supported by a bootstrap value of $99 \%$. The phylogenetic tree based on the neighbour-joining method (Fig. 1) shows the distribution of the six isolates and the phylogenetically closest Micromonospora species. An extended tree including all Micromonospora species with validly published names is available as Supplementary Fig. S2.

To investigate the genetic diversity of the six isolates further, automated riboprinting studies were carried out. Strains were grown for $24-48 \mathrm{~h}$ at $28{ }^{\circ} \mathrm{C}$ on cellulose acetate filters (Microscience) placed over $\mathrm{N}-\mathrm{Z}$ amine agar ( $\mathrm{pH}$ 7.2). Automated riboprinting was performed under the conditions recommended by the manufacturer of the Riboprinter microbial characterization system (Qualicon) using the restriction enzyme PvuII. Two different riboprint profiles (Fig. 2) were clearly distinguished and divided the strains into two homogeneous clusters which corresponded to the phylogenetic groups (A and B) obtained by $16 \mathrm{~S}$ rRNA gene sequence analyses.

To determine overall genome similarity, DNA-DNA hybridization experiments were carried out between $M$. matsumotoense DSM $44100^{\mathrm{T}}$, the closest neighbour according to the phylogenetic analyses, and strains Lupac $09^{\mathrm{T}}$ and Lupac $14 \mathrm{~N}^{\mathrm{T}}$, respectively representing phylogenetic groups

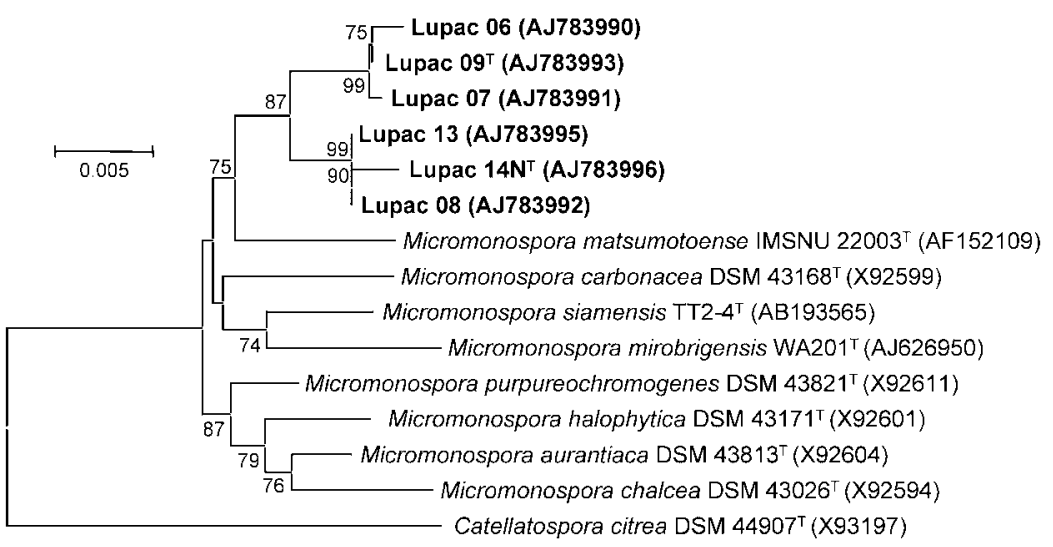

Fig. 1. Neighbour-joining tree based on $16 \mathrm{~S}$
rRNA gene sequences showing the relation-
ships among the six new isolates and the
phylogenetically closest Micromonospora spe-
cies. Bootstrap percentages (from 1000 repli-
cates) above $50 \%$ are shown at nodes. Bar,
0.005 substitutions per nucleotide position. An
extended version of this tree containing all
species of Micromonospora is available as
Supplementary Fig. S2. 


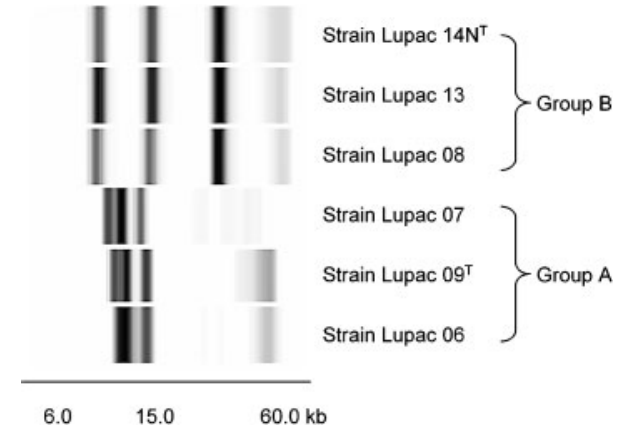

Fig. 2. Riboprint patterns of Micromonospora isolates generated with the restriction enzyme Pvull.

A and B. DNA was isolated and purified on hydroxyapatite (Cashion et al., 1977) and reassociation measurements were obtained by spectrophotometry (De Ley et al., 1970; Huß et al., 1983). These studies revealed low levels of hybridization among the strains tested. Specifically, Lupac $09^{\mathrm{T}}$ and Lupac $14 \mathrm{~N}^{\mathrm{T}}$ shared $27.9 \%$ and $33.2 \%$ relatedness, respectively, with $M$. matsumotoense DSM $44100^{\mathrm{T}}$, while Lupac $09^{\mathrm{T}}$ and Lupac $14 \mathrm{~N}^{\mathrm{T}}$ showed $26 \%$ DNA-DNA relatedness. The $\mathrm{G}+\mathrm{C}$ contents of strains Lupac $09^{\mathrm{T}}$ and Lupac $14 \mathrm{~N}^{\mathrm{T}}$ were 71.6 and $70.9 \mathrm{~mol} \%$, respectively, as determined by the thermal melting method (Mandel \& Marmur, 1968).

Methyl esters of cellular fatty acids for all study strains were prepared from cells grown for $24 \mathrm{~h}$ on trypticase soy agar (Schröder et al., 1997) and analysed using the MIDI system (Microbial ID, Inc.). Diaminopimelic acid (DAP) determination was achieved by cellulose TLC using whole-cell hydrolysates (modified method of Hasegawa et al., 1983; Rhuland et al., 1955). Biomass for additional chemotaxonomic analyses of strains Lupac $09^{\mathrm{T}}$ and Lupac $14 \mathrm{~N}^{\mathrm{T}}$ was obtained in tryptic soy broth in flasks on a rotary shaker at 90 r.p.m. and $28{ }^{\circ} \mathrm{C}$. Whole-cell sugars were analysed according to Staneck \& Roberts (1974). Phospholipids and menaquinones were prepared according to the method of Minnikin et al. (1984) and respectively analysed by twodimensional TLC and HPLC.

Differences in fatty acid composition divided the strains into two groups which corresponded to those defined by the $16 \mathrm{~S}$ rRNA gene sequence and riboprint analyses. The main differences between the two groups were in the amounts of iso-15:0, iso-16:0, iso- $16: 1$ and iso- $17: 0$. The detailed fatty acid patterns of the study strains are presented in Supplementary Table S2. All strains contained meso-DAP. Whole-cell hydrolysates of Lupac $09^{\mathrm{T}}$ and Lupac $14 \mathrm{~N}^{\mathrm{T}}$ contained glucose, mannose, arabinose, xylose and ribose; in addition, Lupac $09^{\mathrm{T}}$ contained rhamnose. Galactose, which has been reported for M. matsumotoense DSM $44100^{\mathrm{T}}$ and M. mirobrigensis DSM $44830^{\mathrm{T}}$, was not found in the new isolates. The menaquinones of strain Lupac $09^{\mathrm{T}}$ were made up of MK-10 $\left(\mathrm{H}_{4}\right)(>90 \%)$ and traces of MK-10 $\left(\mathrm{H}_{6}\right)$, while Lupac $14 \mathrm{~N}^{\mathrm{T}}$ contained these two quinones (83 and $10 \%$, respectively) in addition to MK9( $\left.\mathrm{H}_{4}\right)(7 \%)$. The two strains contained phosphatidylglycerol, phosphatidylinositol and phosphatidylethanolamine, which corresponds to phospholipid pattern II. Overall chemotaxonomic differences found between Lupac $09^{\mathrm{T}}$ and Lupac $14 \mathrm{~N}^{\mathrm{T}}$ and related species are given in Table 1.

Physiological tests for the six isolates were carried out using standard methods and included catalase and oxidase determination (Trujillo et al., 2006a), degradation of various organic compounds (Trujillo et al., 2005), carbon substrate utilization (Williams et al., 1983) and growth at and tolerance of various temperatures $\left(4-45^{\circ} \mathrm{C}\right)$ and $\mathrm{NaCl}$ concentrations (1-5\%). Enzyme activities were also determined using API ZYM and API Coryne kits (bioMérieux) for the six isolates and M. matsumotoense DSM $44100^{\mathrm{T}}, M$. mirobrigensis DSM $44830^{\mathrm{T}}$ and Micromonospora carbonacea DSM $43168^{\mathrm{T}}$.

All strains were catalase- and oxidase-positive with the exception of Lupac 06, which did not produce oxidase. All strains tolerated $1 \% \mathrm{NaCl}$ and grew at $20-37{ }^{\circ} \mathrm{C}$. All strains were negative for nitrate reduction and urease production and were sensitive to $0.01 \%$ sodium azide. Differentiating metabolic profiles of isolates Lupac $09^{\mathrm{T}}$, Lupac $14 \mathrm{~N}^{\mathrm{T}}$ and phylogenetically related Micromonospora type strains are given in Table 1 . The two groups represented by strains Lupac $09^{\mathrm{T}}$ (group A) and Lupac $14 \mathrm{~N}^{\mathrm{T}}$ (group B) could be differentiated by the use of arabinose, trehalose, alanine and sucrose. Pigment production was also considered an important difference between the two groups. Additional physiological data are presented in Table 1 and the species descriptions.

The 16S rRNA gene sequences, cultural characteristics and chemotaxonomic data clearly demonstrate that the six strains isolated from nitrogen-fixing nodules of L. angustifolius belong to the genus Micromonospora. Furthermore, riboprint analyses, fatty acid compositions and metabolic profiles indicate that the strains can be divided into two groups which, according to DNA-DNA hybridization data, represent novel species. Thus, we propose to classify strains Lupac $09^{\mathrm{T}}$, Lupac 06, and Lupac 07 (group A) within the novel species Micromonospora saelicesensis sp. nov. and strains Lupac $14 \mathrm{~N}^{\mathrm{T}}$, Lupac 08 and Lupac 13 (group B) as representatives of the species Micromonospora lupini sp. nov.

\section{Description of Micromonospora saelicesensis sp. nov.}

Micromonospora saelicesensis (saeli.ces.en'sis. N.L. fem. adj. saelicesensis pertaining to Saelices, the place where the plants were collected from which the first strains were isolated).

Gram-positive, chemo-organotrophic and aerobic actinomycete. Well-developed branched hyphae $(0.3-0.6 \mu \mathrm{m}$ in diameter). Colonies are orange on ISP 2 agar. Orangebrown to brown diffusible pigments are produced on ISP 3 
Table 1. Phenotypic characteristics that distinguish the new isolates and phylogenetically related Micromonospora species

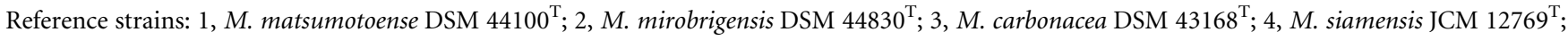
5, M. purpureochromogenes ATCC $27007^{\mathrm{T}}$; 6, M. halophytica DSM $43171^{\mathrm{T}}$. +, Positive; -, negative; ND, no data available; v (+), variable, type strain positive; V (-), variable, type strain negative; w, weak. All API ZYM and API Coryne data were obtained in this study. Other data were taken from Kawamoto (1989), Thawai et al. (2005), Trujillo et al. (2005) and Ara \& Kudo (2007). Fatty acids, whole-cell sugars, menaquinones and polar lipids are listed in decreasing order of abundance.

\begin{tabular}{|c|c|c|c|c|c|c|c|c|}
\hline Characteristic & $\begin{array}{l}\text { M. saelicesensis } \\
\text { sp. nov. }(n=3)\end{array}$ & $\begin{array}{c}\text { M. lupini sp. } \\
\text { nov. }(n=3)\end{array}$ & 1 & 2 & 3 & 4 & 5 & 6 \\
\hline Pigment production & Light orange & - & - & - & - & - & $\begin{array}{l}\text { Dark } \\
\text { brown }\end{array}$ & - \\
\hline Ornamented spores & - & - & $\mathrm{ND}$ & - & + & $\mathrm{ND}$ & + & $\mathrm{ND}$ \\
\hline $\mathrm{NaCl}$ tolerance $(\%)$ & 2 & 1 & 3 & 3 & 3 & 5 & 1.5 & 4 \\
\hline $\begin{array}{l}\text { Maximum growth } \\
\text { temperature }\left({ }^{\circ} \mathrm{C}\right)\end{array}$ & 37 & 37 & 40 & 37 & 40 & 40 & 40 & 40 \\
\hline Nitrate reduction & - & - & + & - & + & - & - & + \\
\hline Starch hydrolysis & $\mathrm{v}(-)$ & + & + & + & + & + & ND & - \\
\hline Xylan hydrolysis & - & + & ND & + & $\mathrm{ND}$ & $\mathrm{ND}$ & - & $\mathrm{ND}$ \\
\hline Oxidase & $\mathrm{v}(+)$ & + & - & + & + & ND & ND & ND \\
\hline \multicolumn{9}{|l|}{ Carbon sources } \\
\hline Arabinose & + & - & + & + & - & + & - & + \\
\hline Trehalose & - & + & + & + & - & $\mathrm{ND}$ & ND & ND \\
\hline Alanine & - & $\mathrm{v}(+)$ & ND & + & $\mathrm{ND}$ & $\mathrm{ND}$ & ND & ND \\
\hline Rhamnose & - & - & - & + & - & + & - & - \\
\hline Histidine & + & - & ND & + & - & $\mathrm{ND}$ & $\mathrm{ND}$ & $\mathrm{ND}$ \\
\hline Inositol & + & - & - & ND & - & $\mathrm{ND}$ & - & $\mathrm{ND}$ \\
\hline Gluconate & - & - & - & $\mathrm{ND}$ & $\mathrm{ND}$ & $\mathrm{ND}$ & $\mathrm{ND}$ & $\mathrm{ND}$ \\
\hline Sucrose & - & + & + & + & $\mathrm{ND}$ & $\mathrm{ND}$ & $\mathrm{ND}$ & + \\
\hline Glutarate & + & $\mathrm{V}(-)$ & ND & ND & $\mathrm{ND}$ & ND & ND & ND \\
\hline Mannitol & + & + & - & - & - & - & - & - \\
\hline \multicolumn{9}{|l|}{$\begin{array}{l}\text { Acid production } \\
\text { from: (API Coryne) }\end{array}$} \\
\hline Glucose & + & - & - & $\mathrm{ND}$ & $\mathrm{ND}$ & $\mathrm{ND}$ & $\mathrm{ND}$ & $\mathrm{ND}$ \\
\hline Maltose & - & - & $\mathrm{w}$ & $\mathrm{ND}$ & $\mathrm{ND}$ & $\mathrm{ND}$ & $\mathrm{ND}$ & $\mathrm{ND}$ \\
\hline \multicolumn{9}{|l|}{ API ZYM results } \\
\hline $\begin{array}{l}\text { Alkaline } \\
\text { phosphatase }\end{array}$ & + & + & - & + & + & $\mathrm{ND}$ & ND & $\mathrm{ND}$ \\
\hline Acid phosphatase & + & + & - & + & + & ND & ND & ND \\
\hline $\begin{array}{l}\text { Naphthol-AS-BI- } \\
\text { phosphohydrolase }\end{array}$ & + & + & - & + & + & $\mathrm{ND}$ & $\mathrm{ND}$ & $\mathrm{ND}$ \\
\hline $\begin{array}{l}N \text {-Acetyl- } \beta \text {-glucos- } \\
\text { aminidase }\end{array}$ & + & + & - & + & + & ND & ND & ND \\
\hline$\alpha$-Mannosidase & $\mathrm{v}(+)$ & - & $\mathrm{W}$ & - & - & ND & - & - \\
\hline$\alpha$-Fucosidase & $\mathrm{v}(+)$ & - & - & - & - & ND & ND & $\mathrm{ND}$ \\
\hline Major fatty acids & $\begin{array}{l}\text { iso- } 15: 0, \text { cis- } 8 \\
17: 1, \text { iso- } 16: 0\end{array}$ & $\begin{array}{r}\text { iso- } 16: 0, \\
\text { iso- } 15: 0\end{array}$ & $\begin{array}{c}\text { iso- } 16: 0,18: 1, \\
17: 1, \\
\text { iso- } 16: 1, \\
\text { iso- } 15: 0\end{array}$ & $\begin{array}{l}\text { iso- } 15: 0 \text {, iso- } \\
16: 0, \text { iso- } 17: 1 \text {, } \\
\text { anteiso- } 17: 0\end{array}$ & $\begin{array}{l}\text { iso- } 15: 0 \text {, } \\
\text { iso- } 16: 0 \text {, } \\
\text { cis-9 } 17: 1\end{array}$ & $\begin{array}{c}\text { iso- } 16: 0, \\
\text { iso- } 15: 0, \\
\text { anteiso- } 17: 0, \\
17: 1\end{array}$ & $\mathrm{ND}$ & $\mathrm{ND}$ \\
\hline Whole-cell sugars* & $\begin{array}{l}\text { Glc, Man, Ara, } \\
\text { Xyl, Rib, Rha }\end{array}$ & $\begin{array}{c}\text { Glc, Man, Ara, } \\
\text { Xyl, Rib }\end{array}$ & $\begin{array}{c}\text { Ara, Xyl, } \\
\text { Gal, Rha }\end{array}$ & $\begin{array}{l}\text { Glc, Gal, } \\
\text { Man, Xyl }\end{array}$ & ND & Xyl, Ara & ND & $\mathrm{ND}$ \\
\hline $\begin{array}{l}\text { Menaquinone } \\
\text { composition }\end{array}$ & $\begin{array}{r}\text { MK-10 }\left(\mathrm{H}_{4}\right) \\
\left.\text { MK-10( } \mathrm{H}_{6}\right)\end{array}$ & $\begin{array}{c}\text { MK-10 }\left(\mathrm{H}_{4}\right) \\
\left.\text { MK-10( } \mathrm{H}_{6}\right) \\
\text { MK-9 }\left(\mathrm{H}_{4}\right)\end{array}$ & $\begin{array}{c}\text { MK-10 }\left(\mathrm{H}_{4}\right) \\
\text { MK-10 }\left(\mathrm{H}_{6}\right) \\
\text { MK-10 }\left(\mathrm{H}_{8}\right)\end{array}$ & $\begin{array}{c}\text { MK-10 }\left(\mathrm{H}_{4}\right), \\
\text { MK-10 }\left(\mathrm{H}_{6}\right), \\
\text { MK-9 }\left(\mathrm{H}_{4}\right)\end{array}$ & MK-9 $\left(\mathrm{H}_{4}\right)$ & $\begin{array}{l}\text { MK-10 }\left(\mathrm{H}_{4}\right) \\
\left.\text { MK-10( } \mathrm{H}_{6}\right)\end{array}$ & $\begin{array}{l}\text { MK- } \\
10\left(\mathrm{H}_{4}\right)\end{array}$ & $\begin{array}{l}\text { MK- } \\
9\left(\mathrm{H}_{4}\right)\end{array}$ \\
\hline Major polar lipids $\dagger$ & DPG, PE, PI & DPG, PE, PI & $\begin{array}{c}\text { DPG, PI, PG, } \\
\text { PE }\end{array}$ & PI, DPG, PE & ND & PE, DPG, PI & $\mathrm{ND}$ & ND \\
\hline
\end{tabular}

*Ara, Arabinose; Gal, galactose; Glc, glucose; Man, mannose; Rha, rhamnose; Rib, ribose; Xyl, xylose.

$\dagger$ DPG, Diphosphatidylglycerol; PE, phosphatidylethanolamine; PG, phosphatidylglycerol; PI, phosphatidylinositol. 
agar. Smooth-surfaced spores are produced at the tip of the hyphae. Growth occurs at $20-37{ }^{\circ} \mathrm{C}$ but not at 15 or $45^{\circ} \mathrm{C}$; optimum growth at $28{ }^{\circ} \mathrm{C}$. Catalase-positive and oxidasevariable. Nitrate is not reduced. Growth is observed in $2 \%$ $\mathrm{NaCl}$ but not in the presence of $0.001 \%$ crystal violet or $0.01 \%$ sodium azide. Arbutin, casein, aesculin, gelatin and xylan are degraded, but not tyrosine. Starch degradation is variable. Carbon sources assimilated include arabinose, cellobiose, galactose, glutarate, histidine, inositol, maltose, mannose, melibiose, raffinose and sucrose. Alanine, arginine, gluconate, lysine, proline, rhamnose, serine, sorbitol, sorbose, sucrose, trehalose, valine and xylitol are not assimilated. Enzyme tests with the API ZYM and API Coryne systems are positive for acid and alkaline phosphatases, esterase (C4), esterase lipase (C8), lipase (C15), leucine arylamidase, cystine arylamidase, trypsin, $\alpha$ chymotrypsin, naphthol-AS-BI-phosphohydrolase, $\alpha$ galactosidase, $\beta$-galactosidase, $\alpha$-glucosidase, $\beta$-glucosidase, $N$-acetyl- $\beta$-glucosaminidase and pyrazinamidase and negative for $\beta$-glucuronidase, pyrrolidonyl arylamidase, urease and $\beta$-glucuronidase. Variable reactions are observed for $\alpha$ mannosidase and $\alpha$-fucosidase. Acid is produced from glucose. Peptidoglycan contains meso-DAP; whole-cell sugars are glucose, mannose, arabinose, xylose, ribose and rhamnose. Major menaquinone is $\mathrm{MK}-10\left(\mathrm{H}_{4}\right)$. Diagnostic phospholipid is diphosphatidylethanolamine. The $\mathrm{G}+\mathrm{C}$ content of the type strain is $71.6 \mathrm{~mol} \%$.

The type strain, Lupac $09^{\mathrm{T}}\left(=\mathrm{DSM} 44871^{\mathrm{T}}=\mathrm{LMG}\right.$ $\left.24056^{\mathrm{T}}\right)$, and two other strains, Lupac 06 (=DSM 44868) and Lupac 07 (=DSM 44869), were isolated from root nodules of Lupinus angustifolius.

\section{Description of Micromonospora lupini sp. nov.}

Micromonospora lupini (lu' pin.i. L. gen. n. lupini of a lupin, referring to the isolation of the first strains from Lupinus angustifolius).

Gram-positive, chemo-organotrophic and aerobic actinomycete. Well-developed branched hyphae $(0.3-0.6 \mu \mathrm{m}$ in diameter). Colonies are light orange on ISP 2 agar. No diffusible pigments are observed. Smooth-surfaced spores are produced at the tip of the hyphae. Growth occurs at $20-37{ }^{\circ} \mathrm{C}$ but not at 15 or $45^{\circ} \mathrm{C}$; optimum growth at $28{ }^{\circ} \mathrm{C}$. Catalase- and oxidase-positive. Nitrate is not reduced. Growth is observed at $1 \% \mathrm{NaCl}$ but variable at $2 \% \mathrm{NaCl}$. No growth in $0.001 \%$ crystal violet or $0.01 \%$ sodium azide. Arbutin, casein, aesculin, gelatin, starch and xylan are degraded but not tyrosine. Carbon sources assimilated include alanine, cellobiose, galactose, maltose, mannose, melibiose, raffinose and trehalose. Arginine, histidine, lysine, proline, rhamnose, serine, sorbitol, sorbose, tyrosine, valine and xylitol are not assimilated. Enzyme tests with the API ZYM and API Coryne systems are positive for acid and alkaline phosphatases, esterase (C4), esterase lipase (C8), lipase (C15), leucine arylamidase, cystine arylamidase, trypsin, $\alpha$-chymotrypsin, naphthol-ASBI-phosphohydrolase, $\alpha$-galactosidase, $\beta$-galactosidase, $\alpha$-glucosidase, $\beta$-glucosidase, $N$-acetyl- $\beta$-glucosaminidase and pyrazinamidase and negative for $\beta$-glucuronidase, $\alpha$ mannosidase, $\alpha$-fucosidase and urease. Acid is not produced from glucose. Peptidoglycan contains meso-DAP; whole-cell sugars are glucose, mannose, arabinose, xylose and rhamnose. Major menaquinone is MK- $10\left(\mathrm{H}_{4}\right)$. Diagnostic phospholipid is diphosphatidylethanolamine. The $\mathrm{G}+\mathrm{C}$ content of the type strain is $70.9 \mathrm{~mol} \%$. Strain Lupac 08 produces the antitumoral compounds lupinadicins $\mathrm{A}$ and $\mathrm{B}$.

The type strain, Lupac $14 \mathrm{~N}^{\mathrm{T}}\left(=\mathrm{DSM} 44874^{\mathrm{T}}=\mathrm{LMG}\right.$ $24055^{\mathrm{T}}$ ), and two other strains, Lupac 08 (=DSM 44870) and Lupac 13 (=DSM 44873), were isolated from root nodules of Lupinus angustifolius.

\section{Acknowledgements}

We would like to thank Dr J. P. Euzéby for his help with the nomenclature. We also acknowledge the excellent technical assistance of Mrs G. Pötter and other DSMZ staff. M.E.T. and E.M.M. are grateful to the Ministerio de Educación y Ciencia (MEC) for financial support under the project CGL2006-06988. M.E. T. also thanks the European Union for financial support under the BIOREMAT programme.

\section{References}

Ara, I. \& Kudo, T. (2007). Two new species of the genus Micromonospora: Micromonospora chokoriensis sp. nov. and Micromonospora coxensis sp. nov., isolated from sandy soil. J Gen Appl Microbiol 53, 29-37.

Cashion, P., Holder-Franklin, M. A., McCully, J. \& Franklin, M. (1977). A rapid method for the base ratio determination of bacterial DNA. Anal Biochem 81, 461-466.

Chun, J., Lee, J.-H., Jung, Y., Kim, M., Kim, S., Kim, B. K. \& Lim, Y.-W. (2007). EzTaxon: a web-based tool for the identification of prokaryotes based on 16S ribosomal RNA gene sequences. Int J Syst Evol Microbiol 57, 2259-2261.

De Ley, J., Cattoir, H. \& Reynaerts, A. (1970). The quantitative measurement of DNA hybridization from renaturation rates. Eur $J$ Biochem 12, 133-142.

Doetsch, R. N. (1981). Determinative methods of light microscopy. In Manual of Methods for General Bacteriology, pp. 21-33. Edited by P. Gerhardt, R. G. E. Murray, R. N. Costilow, E. W. Nester, W. A. Wood, N. R. Krieg \& G. B. Phillips. Washington, DC: American Society for Microbiology.

Fitch, W. M. (1971). Toward defining the course of evolution: minimum change for a specific tree topology. Syst Zool 20, 406-416.

Hasegawa, T., Takizawa, M. \& Tanida, S. (1983). A rapid analysis for chemical grouping of aerobic actinomycetes. J Gen Appl Microbiol 29, 319-322.

Huß, V. A. R., Festl, H. \& Schleifer, K. H. (1983). Studies on the spectrophotometric determination of DNA hybridization from renaturation rates. Syst Appl Microbiol 4, 184-192.

Jones, K. L. (1949). Fresh isolates of actinomycetes in which the presence of sporogenous aerial mycelia is a fluctuating characteristic. J Bacteriol 57, 141-145.

Kawamoto, I. (1989). Genus Micromonospora Ørskov 1923, $147^{\mathrm{AL}}$. In Bergey's Manual of Systematic Bacteriology, vol. 4, pp. 2442-2450. 
Edited by S. T. Williams, M. E. Sharpe \& J. G. Holt. Baltimore: Williams \& Wilkins.

Kimura, M. (1980). A simple method for estimating evolutionary rates of base substitutions through comparative studies of nucleotide sequences. J Mol Evol 16, 111-120.

Kroppenstedt, R. M. (1985). Fatty acid and menaquinone analysis of actinomycetes and related organisms. In Chemical Methods in Bacterial Systematics (Society for Applied Bacteriology Technical Series vol. 20), pp. 173-199. Edited by M. Goodfellow \& D. E. Minnikin. New York: Academic Press.

Kumar, S., Tamura, K. \& Nei, M. (2004). MEGA3: integrated software for molecular evolutionary genetics analysis and sequence alignment. Brief Bioinform 5, 150-163.

Lechevalier, M. P. \& Lechevalier, H. A. (1970). Chemical composition as a criterion in the classification of aerobic actinomycetes. Int J Syst Bacteriol 20, 435-443.

Lechevalier, M. P., De Bièvre, C. \& Lechevalier, H. A. (1977). Chemotaxonomy of aerobic actinomycetes: phospholipid composition. Biochem Syst Ecol 5, 249-260.

Maldonado, L. A., Stach, J. E. M., Pathom-aree, W., Ward, A. C., Bull, A. T. \& Goodfellow, M. (2005). Diversity of cultivable actinobacteria in geographically widespread marine sediments. Antonie van Leeuwenhoek 87, 11-18.

Mandel, M. \& Marmur, J. (1968). Use of ultraviolet absorbance temperature profile for determining the guanine plus cytosine content of DNA. Methods Enzymol 12B, 195-206.

Minnikin, D. E., O'Donnell, A. G., Goodfellow, M., Alderson, G., Athalye, M., Schaal, A. \& Parlett, J. H. (1984). An integrated procedure for the extraction of bacterial isoprenoid quinones and polar lipids. J Microbiol Methods 2, 233-241.

Orskov, J. (1923). Investigation into the Morphology of the Ray Fungi. Copenhagen: Levin \& Munksgaard.

Rhuland, L. E., Work, E., Denman, R. F. \& Hoare, D. S. (1955). The behavior of the isomers of $\alpha, \varepsilon$-diaminopimelic acid on paper chromatograms. J Am Chem Soc 77, 4844-4846.

Rivas, R., Sánchez, M., Trujillo, M. E., Zurdo-Piñeiro, J. L., Mateos, P. F., Martínez-Molina, E. \& Velázquez, E. (2003). Xylanimonas cellulosilytica gen. nov., sp. nov., a xylanolytic bacterium isolated from a decayed tree (Ulmus nigra). Int J Syst Evol Microbiol 53, 99-103.

Saitou, N. \& Nei, M. (1987). The neighbor-joining method: a new method for reconstructing phylogenetic trees. Mol Biol Evol 4, 406-425.
Schröder, K.-H., Naumann, L., Kroppenstedt, R. M. \& Reischl, U. (1997). Mycobacterium hassiacum sp. nov., a new rapidly growing thermophilic mycobacterium. Int J Syst Bacteriol 47, 86-91.

Shirling, E. B. \& Gottlieb, D. (1966). Methods for characterization of Streptomyces species. Int J Syst Bacteriol 16, 313-340.

Stackebrandt, E., Rainey, F. A. \& Ward-Rainey, N. L. (1997). Proposal for a new hierarchic classification system, Actinobacteria classis nov. Int J Syst Bacteriol 47, 479-491.

Staneck, J. L. \& Roberts, G. D. (1974). Simplified approach to the identification of aerobic actinomycetes by thin layer chromatography. Appl Microbiol 28, 226-231.

Thawai, C., Tanasupawat, S., Itoh, T., Suwanborirux, K. \& Kudo, T. (2005). Micromonospora siamensis sp. nov., isolated from Thai peat swamp forest. J Gen Appl Microbiol 51, 229-234.

Trujillo, M. E., Fernández-Molinero, C., Velázquez, E., Kroppenstedt, R. M., Schumann, P., Mateos, P. F. \& Martínez-Molina, E. (2005). Micromonospora mirobrigensis sp. nov. Int J Syst Evol Microbiol 55, 877-880.

Trujillo, M. E., Kroppenstedt, R. M., Schumann, P. \& MartínezMolina, E. (2006a). Kribbella lupini sp. nov., isolated from the roots of Lupinus angustifolius. Int J Syst Evol Microbiol 56, 407-411.

Trujillo, M. E., Kroppenstedt, R. M., Schumann, P., Carro, L. \& Martínez-Molina, E. (2006b). Micromonospora coriariae sp. nov., isolated from root nodules of Coriaria myrtifolia. Int J Syst Evol Microbiol 56, 2381-2385.

Valdés, M., Pérez, N.-O., Estrada-de los Santos, P., CaballeroMellado, J., Peña-Cabriales, J. J., Normand, P. \& Hirsch, A. M. (2005). Non-Frankia actinomycetes isolated from surface-sterilized roots of Casuarina equisetifolia fix nitrogen. Appl Environ Microbiol 71, 460-466.

Vincent, J. M. (1970). The cultivation, isolation and maintenance of rhizobia. In A Manual for the Practical Study of the Root-Nodule Bacteria, pp. 1-13. Edited by J. M. Vincent. Oxford: Blackwell Scientific.

Williams, S. T., Goodfellow, M., Alderson, G., Wellington, E. M. H., Sneath, P. H. A. \& Sackin, M. J. (1983). Numerical classification of Streptomyces and related genera. J Gen Microbiol 129, 1743-1813.

Zhao, H., Kassama, Y., Young, M., Kell, D. B. \& Goodacre, R. (2004). Differentiation of Micromonospora isolates from a coastal sediment in Wales on the basis of Fourier transform infrared spectroscopy $16 \mathrm{~S}$ rRNA sequence analysis, and the amplified fragment length polymorphism technique. Appl Environ Microbiol 70, 6619-6627. 